\title{
Insulin-Like Growth Factor Binding Proteins in Autoimmune Diseases
}

\author{
Huihua Ding ${ }^{1}$ and Tianfu $W u^{2 *}$ \\ 'Department of Rheumatology, Renji Hospital, Shanghai Jiao Tong University School of Medicine, Shanghai, China, \\ ${ }^{2}$ Department of Biomedical Engineering, University of Houston, Houston, TX, United States
}

\section{OPEN ACCESS}

Edited by:

Pierre De Meyts,

de Duve Institute, Belgium

Reviewed by:

Guillermo Romero,

University of Pittsburgh, United States

Alain Couvineau,

Institut National de la Santé et de la

Recherche Médicale (INSERM),

France

Wendie Cohick

Rutgers University, The State

University of New Jersey,

United States

*Correspondence:

Tianfu Wu

twu13@central.uh.edu

Specialty section:

This article was submitted to

Molecular and Structural

Endocrinology,

a section of the journa

Frontiers in Endocrinology

Received: 21 February 2018

Accepted: 08 August 2018

Published: 30 August 2018

Citation:

Ding H and Wu T (2018) Insulin-Like Growth Factor Binding Proteins in

Autoimmune Diseases.

Front. Endocrinol. 9:499

doi: 10.3389/fendo.2018.00499
Insulin-like growth factor binding proteins (IGFBPs) are a family of proteins binding to Insulin-like growth factors (IGFs), generally including IGFBP1, IGFBP2, IGFBP3, IGFBP4, IGFBP5, and IGFBP6. The biological functions of IGFBPs can be classified as IGFs-dependent actions and IGFs-independent effects. In this review, we will discuss the structure and function of various IGFBPs, particularly IGFBPs as potential emerging biomarkers and therapeutic targets in various autoimmune diseases, and the possible mechanisms by which IGFBPs act on the pathogenesis of autoimmune diseases.

Keywords: IGFBPs, autoimmune diseases, biomarkers, therapeutic targets, metabolism

\section{INTRODUCTION}

Insulin-like growth factor binding proteins (IGFBPs) are a group of secreted proteins which serve as transport proteins for insulin-like growth factors (IGFs) with high affinity, regulating the bioavailability and function of IGFs. The IGFBP family consists of six IGFBPs, namely IGFBP1 through IGFBP6, however other proteins with low binding affinity to IGFs were incorrectly named as IGFBP7, IGFBP8, IGFBP9 etc., a consequence of belonging to the IGFBP-related protein (IGFBP-rPs) family $(1,2)$. Due to the conserved protein structure and high binding affinity to IGFs, only IGFBP1 through IGFBP6 are considered true IGFBPs. The eponymous function of IGFBPs is achieved through binding to IGFs thus regulating their biological activity; however, in pathological conditions, especially under cancer status, the role of IGFBPs in IGF-independent pathways has prompted increasing attention (3). In autoimmune diseases, IGFBPs are also known to play a role in the development of diseases both through IGF-dependent and IGF-independent pathologies $(4,5)$. In this review, we focus on the six true IGFBPs and their roles in autoimmune diseases, including their potential roles as biomarkers and therapeutic targets.

\section{THE IGFBP FAMILY: STRUCTURE AND FUNCTION}

The IGFBP family comprises six structurally similar proteins with high affinity to IGFs. The six proteins, with a mass of $\sim 24$ to $50 \mathrm{kDa}$ (216-289 amino acids), share a highly conserved structure with three domains of similar sizes: the conserved N-terminal cysteine rich region and the $\mathrm{C}$-terminal cysteine rich region connected by a less structural and less conserved linker region $(6,7)$ (Figure 1). High-affinity IGFs binding capacity requires both the N- and C-terminals, with relative IGFs-binding affinities differ among IGFBPs (6). The linker domain is highly variable and unique to each IGFBPs; It's involved in the proteolysis of IGFBPs by several proteases, with cleavage sites located in the domain (7-9). The proteolysis of IGFBPs results in IGFs release, which provides a mechanism for the post-translational modification of IGFBPs. Other post-transcriptional modifications, such as glycosylation and phosphorylation, have also been 
implicated in this region which can modulate the function of IGFBPs (10-12). The linker domain also indirectly plays a role in high affinity IGF binding through inter-domain movement control during ligand binding (13).

The biological function of IGFBPs can be classified as IGFsdependent actions and IGFs-independent effects. Both IGF-I and IGF-II are protein hormones structurally and functionally similar to insulin, which play extensive roles in growth and development. When binding to insulin-like growth factor 1 receptor (IGF1R), IGFs activate the intracellular IGF signaling pathway and promote cell proliferation and differentiation as well as inhibit cell apoptosis $(14,15)$. In blood, most IGFs $(\sim 75 \%)$ circulate as a $150 \mathrm{kDa}$ ternary complex containing IGFs bound to IGFBP3 and a glycoprotein called acid labile subunit (ALS) (16-18). The rest of IGFs $(\sim 25 \%)$ are bound to the six IGFBPs to form a $50 \mathrm{kDa}$ binary complex. It is through this binding that IGFBPs regulate the bioavailability of IGFI and IGF-II in a range of ways. Firstly, they transport and store IGFs in circulation such that IGFs are more stable with an extended half-life of several hours in ternary complex and several minutes in a binary complex (16). Secondly, IGFBPs modulate the action of IGFs in both positive and negative manners. Since IGFBPs have higher affinity to IGFs than IGF1R, the binding of IGFBPs to IGFs sequestrate IGFs from their receptors inhibiting the effects of IGFs (19-21). This inhibitory effect has been widely proved in the case of IGFBP4 in both in vitro and in vivo studies (22-24). On the other hand, some IGFBPs (IGFBP1, IGFBP3, IGFBP5) may stimulate IGF actions in certain circumstances.

The IGF independent action of IGFBPs include effects on cell adhesion and migration, cell growth and apoptosis $(19,25)$. IGFBP1 was reported to increase cell migration of Chinese hamster ovary $(\mathrm{CHO})$ cells, which was mediated through the binding of RGD motif in C-terminal of IGFBP1 to $\alpha_{5} \beta_{1}$ integrin (26). In human carotid plaques, the expression of IGFBP1 is significantly increased and IGFBP1 has been proven to stimulate smooth muscle cells proliferation through ERK1/2 activation (27). Both the intact and proteolyzed form of IGFBP3 have been demonstrated to have IGF-independent growth-stimulatory and inhibitory effects in several cell lines including a range of cancer cell lines (28-34). IGFBP3 also protects against retinal endothelial cell apoptosis through inhibition of TNF- $\alpha$ production (35). In the respiratory system, IGFBP3 treatment reduces airway inflammation and hyper-responsiveness via activation of IGFBP3 receptor pathway (36). IGFBP5 fragments were first shown to stimulate osteoblast mitogenesis in the absence of IGF-I and recombinant human IGFBP5 stimulated osteoblast proliferation without the aid of IGF-I (37-39). Using genetic engineering, Pell JM et al proved that IGFBP5 played an important role in cell proliferation and apoptosis both in vitro and in vivo via an IGF-independent mechanism (40,41). Due to the different structures of various IGFBPs, the expression, binding kinetics and dynamics may vary in a dose-dependent manner at temporal and spatial levels and may all contribute to the specific functions of IGFBPs at different physiological situations.

\section{IGFBPS AS BIOMARKERS IN AUTOIMMUNE DISEASES}

The past few decades have witnessed a growing interest in the exploration of biomarkers in human diseases. This growth is fueled by the biological functions of biomarkers as they can be used as diagnostic tool to improve the accuracy of diagnosis, possible early detection of diseases, monitoring markers allowing for elucidation of disease activity and complications. Furthermore, they can also be used as prognostic markers allowing for prediction of possible patient outcomes.

IGFBP family members have been indicated to be involved in the development and progression of tumors and may be useful prognostic biomarkers in various malignancies (3). Recent studies also validated IGFBPs' role in the diagnosis and prognosis prediction in some solid tumor including nasopharyngeal carcinoma, ovarian cancer, pancreatic cancer, etc. (42-46). Despite the huge development of IGFBPs as biomarkers in cancer, there have been a number of studies focusing on the utility of IGFBPs as biomarkers in autoimmune diseases (Table 1). Despite the advances of researches on IGFBPs as biomarkers in cancer, there have been several studies focusing on the utility of IGFBPs as biomarkers in autoimmune diseases (Table 1), most of which were investigating the diagnostic role of IGFBPs in the disease. While the potential role of IGFBPs as diagnostic biomarkers has been summarized below, the mechanism of action for these molecules has not been widely investigated. Here we summarized studies investigating the potential roles of IGFBPs in the diagnosis and monitor of autoimmune diseases.

\section{Type 1 Diabetes Mellitus (T1DM)}

Type 1 diabetes mellitus (T1DM) is an organ-specific autoimmune disease in which the insulin-producing pancreatic $\beta$ cells are destroyed by the immune system. Due to the close relationship to insulin, the system of IGF and its binding proteins has been first explored as biomarkers in diabetes, especially T1DM. Serum IGFBP1 levels were consistently reported to be increased in T1DM population including prepubertal and pubertal individuals (47-52). In children with new onset diabetes, serum IGFBP1 served as a differential diagnostic marker for T1DM and T2DM (50). In young T1DM patients, IGFBP1 levels were increased independent of pubertal status (52). Besides being a diagnostic marker, serum IGFBP1 level was a good indicator of complications related to T1DM. In T1DM patients complicated with microalbuminuria, serum IGFBP1 level has been reported to be significantly increased (53). It's also a biomarker for diabetic retinopathy in T1DM but not T2DM patients (54). Serum IGFBP2 levels were also reported as an increased biomarker in $\operatorname{T1DM}(53,55)$. In a recent study, Zhi et al. used a proteomic approach to identify IGFBP2 as a potential diagnostic biomarker for T1DM (56). However, in diabetic retinopathy, IGFBP2 levels have been reported to be either increased or decreased in T1DM patients $(51,54)$. IGFBP3, the most abundant type of IGFBPs, has been widely studied as biomarker in T1DM. In T1DM patients, serum 

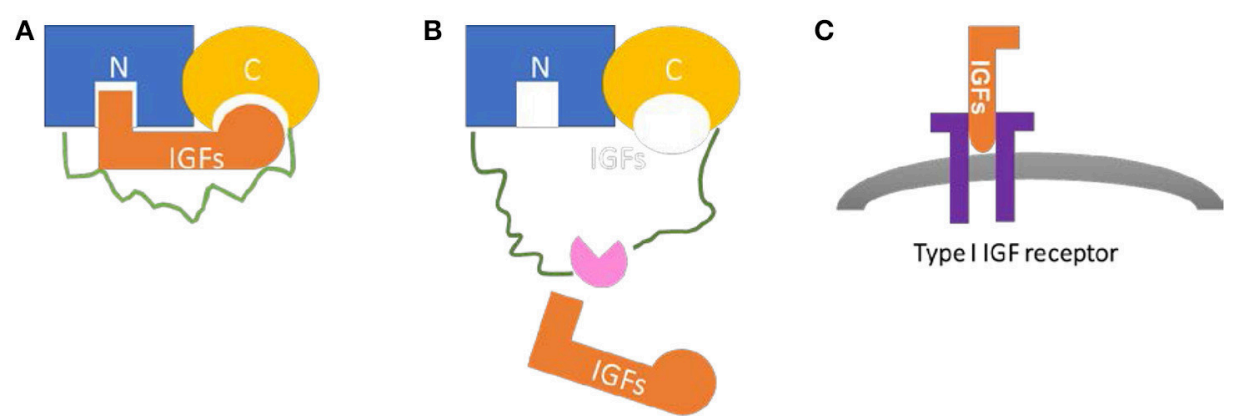

FIGURE 1 | Common structure and biological function of IGFBPs. (A) The N-terminal region (blue) and the C-terminal region (yellow) are connected by a linker region (green). Both N-domain and C-domain contains a binding site for IGFs (orange). (B) The proteolysis of IGFBPs by various proteases (pink) occurs in the linker region or other post-translational modifications, may result in IGFs release. (C) Once released from IGFBPs, IGFs bind to IGF receptors (purple) to exert their physiological effects.

TABLE 1 | Summary of IGFBPs as biomarkers in autoimmune diseases.

\begin{tabular}{|c|c|c|c|c|c|c|c|}
\hline Autoimmune disease & GFBP1 & IGFBP2 & IGFBP3 & IGFBP4 & IGFBP5 & IGFBP6 & References \\
\hline Type I diabetes & $\uparrow$ & $\uparrow / \downarrow$ & $\uparrow /-$ & $\uparrow$ & & $\downarrow$ & $(47-63)$ \\
\hline Multiple sclerosis & $\uparrow /-$ & $\uparrow /-$ & $\uparrow / \downarrow /-$ & & & & $(64-70)$ \\
\hline Rheumatoid arthritis & & $\uparrow$ & Synovial fluid $\uparrow$, Serum $\uparrow / \downarrow$ & & & & $(71-83)$ \\
\hline Juvenile idiopathic arthritis & & & Synovial fluid $\downarrow$, Serum $\downarrow$ & & & & $(84-86)$ \\
\hline Systemic lupus erythematosus & & $\uparrow$ & & $\uparrow$ & & & $(87-90)$ \\
\hline Systemic sclerosis & & & $\uparrow$ & & $\uparrow$ & & $(91-93)$ \\
\hline Inflammatory bowel disease & & $\uparrow$ & & & & & (94) \\
\hline
\end{tabular}

$\uparrow$, means increased in serum; -, means no change; $\downarrow$, means decreased in serum.

IGFBP3 levels have reported to be significantly decreased in different populations, which was partially explained by increased proteolysis $(47,48,53,55,56)$. However, in T1DM women during pregnancy, serum IGFBP3 levels have been implicated to either increase or decrease, which might be explained by the different testing time period $(57,58)$. IGFBP3 level also worked as a severity marker for T1DM. It correlated with HbA1c, total cholesterol, and LDL-cholesterol levels (59) and inversely correlated with blood pressure (60). Besides, patients complicated with autoimmune thyroiditis and coeliac disease had significantly lower serum concentration of IGFBP3 (61). More interestingly, IGFBP3 levels were significantly increased in the tears of diabetic patients, indicating the potential contribution to pathogenesis of ocular complications in diabetes (62). IGFBP4 was only reported in one study to be significantly increased in prepubertal T1DM children (47). More recently, higher IGFBP4 fragment levels was reported to be associated with cardiovascular mortality rates in T1DM patients, which made it a potential prognostic biomarker (63). Decreased IGFBP6 was reported to be related with diabetic retinopathy in both T1DM and T2DM (54).

\section{Multiple Sclerosis (MS)}

Multiple sclerosis (MS) is a demyelinating autoimmune disease in which the immune system damages the myelin sheath of the nerve cells in the central nervous system. The first study investigating IGFBPs concentrations in MS patients revealed no differences in concentrations of IGFBP1, IGFBP2, and IGFBP3 in circulation and cerebrospinal fluid between MS patients and controls (64). Later on, with the enlargement of study population size, Al-Temaimi et al. reported an increased IGFBP1 level in female MS patients (65). Consistent with this, IGFBP1 as well as IGFBP6 were proven to be overexpressed in oligodendrocytes at the edges of demyelinated plaques, indicating a pathogenic role of them in the development of MS (66). Other studies focused on the serum concentration of IGFBP3 in MS, but the results lacked consistency (67-70). This inconsistency of IGFBP3 levels in MS patients may be due to the differences of sample size and patients' demographic characteristics. However, IGFBP3 level correlated with disease severity score, relapsing-remitting disease pattern and treatment strategy, indicating the involvement of IGFBP3 in the pathogenesis of MS $(67,69,70)$. Serum IGFBP2 was reported to be increased in MS patients compared to healthy control (69).

\section{Rheumatoid Arthritis (RA)}

Rheumatoid arthritis (RA) is systemic inflammatory disease that primarily affects the joints. The profile of IGFBPs were first characterized in the synovial fluid of RA patients, in which IGFBP2, IGFBP3, and IGFBP4 levels were significantly elevated compared to normal individuals or osteoarthritis patients (7174). IGFBP3 levels in the synovial fluid of RA patients correlated with systemic C-reactive protein (CRP) levels, indicating the 
involvement of IGFBP3 in inflammation (73). Unlike the synovial fluid, IGFBPs profiling in circulation of RA patients remains controversial. Early studies demonstrated a decreased serum level of IGFBP3 in RA patients $(73,75,76)$, which correlated with habitual exercise level (75). However, other groups didn't observe the effect of dynamic exercise on serum IGFBP3 (77, 78). Toussirot et al. compared serum IGFBP3 levels in corticosteroid-treated RA patients, non-RA patients under corticosteroids treatment, and healthy population (79). No significant differences were observed. More recently, a number of studies have demonstrated an increased IGFBP3 levels in RA patients, which correlated with serum CRP level (80-82). The inconsistency of circulating IGFBP3 levels in RA patients could be due to the heterogeneity of RA population as well as differences in disease status and treatment since the treatment strategy for RA has been changed dramatically over time. Other than IGFBP3, serum IGFBP2 and IGFBP1 have been reported to increase in RA population $(81,83)$.
In juvenile idiopathic arthritis, the expression of IGFBP3 was decreased both in the circulation and synovial fluid (8486).

\section{Systemic Autoimmune Diseases}

Systemic autoimmune diseases such as systemic lupus erythematosus (SLE), systemic sclerosis, inflammatory bowel disease and idiopathic pulmonary fibrosis have also been reported to be associated with IGFBPs (87-91, 94, 95). In SLE, IGFBP2, IGFBP4 and IGFBP6 were discovered by arraybased proteomic screening as diagnostic biomarkers for lupus (89). Later validation studies using a larger study population confirmed the role of IGFBP2 as a diagnostic biomarker for SLE as well as lupus nephritis $(88,90)$.

Moreover, IGFBP2 is a potential disease monitoring biomarker for renal function and renal histopathologic changes in lupus nephritis (88). Another SLE marker, IGFBP4, was mainly increased in lupus nephritis patients, which makes it

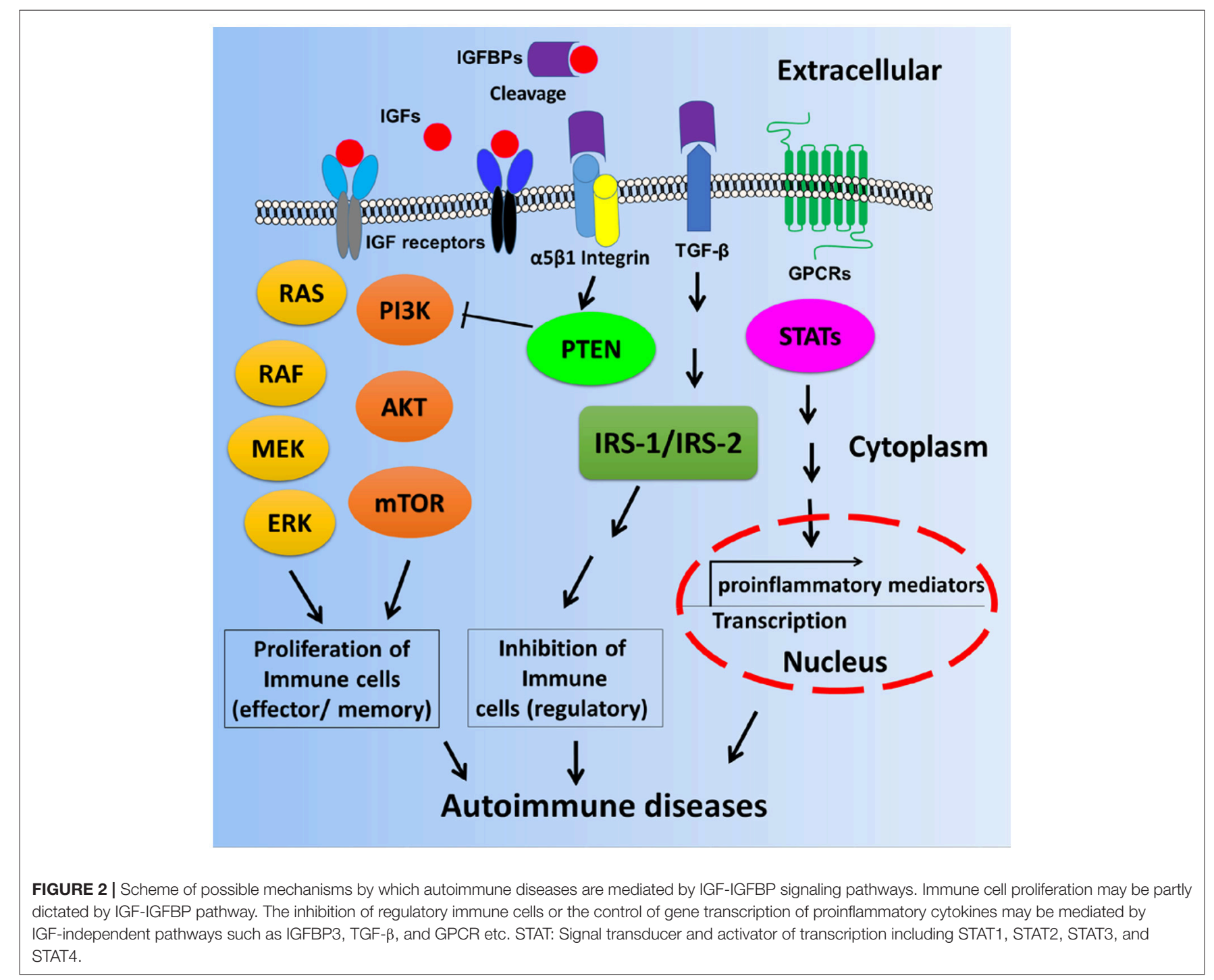


a good indicator for renal pathology chronicity changes (87). In systemic sclerosis, serum IGF-1 and IGFBP-3 levels were significantly elevated compared to SLE patients or healthy control (91). Yasuoka et al. demonstrated the overexpression of IGFBP5 in animal models of systemic sclerosis could induce fibrosis in the lung and the skin $(92,93)$. In inflammatory bowel disease patients, serum proteome profiling revealed elevated IGFBP2 levels in untreated patients and suppressed by steroids treatment, indicating the pro-inflammatory effect of IGFBP2 (94). Serum IGFBP1 and IGFBP2 are elevated in idiopathic pulmonary fibrosis patients and IGFBP2 level was significantly reduced by anti-fibrotic therapy (95).

All these studies suggest that IGFBPs are indicative of disease activity, although larger cohort of patients are still needed to validate these findings. Nevertheless, it is expected that these IGFBPs molecules may be involved in the pathogenesis of these autoimmune diseases and may serve as disease biomarkers to monitor flares or track drug responses.

\section{IGFBPS IN AUTOIMMUNE DISEASES: POSSIBLE MECHANISMS}

Although IGFBPs have been proved as potential biomarkers in a variety of autoimmune diseases, the underlying mechanism remains unveiled. Given that the biological function of IGFBPs can be divided into IGFs-dependent and independent effects, the underlying mechanism of IGFBPs in autoimmune diseases can also be divided into IGFs-dependent and IGFs-independent mechanisms. Immune regulation of IGF-I has been reviewed in detail elsewhere (96). A recent genome-wide association study (GWAS) in SLE patients suggested that serum IGF-1 levels were increased with SLE disease severity, and SLE may be affected by a modulation of the IGF-1 signaling pathway and +3179G/A IGF-1R polymorphism (97).

The following studies suggested that IGFBPs have direct effects on immunity and inflammation. Peripheral blood mononuclear cells (PBMC) mainly consist of lymphocytes and monocytes, representing cells of both the innate and adaptive immune systems. Early study demonstrated an inhibitory effect of IGFBP1 on the proliferation of activated PBMCs (98). However, an increase of IGFBP2 expression was indicated in activated human PBMCs and exogenous IGFBP2 treatment of enhanced the proliferation of human PBMCs, suggesting the involvement of IGFBP2 in lymphocyte proliferation (98). Intratracheal administration of IGFBP5 in mice induced mononuclear cell infiltration in the lung and in vitro IGFBP5 can stimulate migration of PBMCs (93). This monocyte/macrophage system contributes to autoimmune diseases and inflammation by phagocytosis and antigen presentation. Furthermore, several studies have demonstrated the impact of different IGFBPs on monocyte/macrophage. An increase of IGFBP3 expression was first reported to be related with increased monocyte apoptosis stimulated by lipopolysaccharide, which was proved to be IGF independent (99). Recently, IGFBP3 was demonstrated to inhibit monocyte-endothelial cell adhesion through down-regulate ICAM-1 expression under hyperglycemic condition, which can inhibit retinal inflammation (100). In the RA synovium, IGFBP3 was produced by macrophage (82). In a mouse model of lung fibrosis, IGFBP5 induced migration of activated CD4+T cells and monocytes, indicating a chemoattractant activity of IGFBP5 for immune cells (101). In the same model, monocytes treated with IGFBP5 acquired a mesenchymal phenotype in vitro and in vivo (101). in vitro culture of human hematopoietic stem cells revealed an inhibitory effect of IGFBP3 and a stimulatory effect of IGFBP6 on the development of pro-B-cell, which might be IGF-1 dependent (102). IGFBP3 was also proved to support the development and maintenance of naïve CD8 $+\mathrm{T}$ cells, indicating the beneficial impact of IGFBP3 in maintaining a health immune system (103). IGFBP2 supplement can maintain vigorous hematopoietic cell expansion and CD34+ phenotype (104).

These interesting findings suggest that IGFBPs may be involved in the pathogenesis of various autoimmune diseases, either via IGF-1 dependent signaling pathways or IGF-1 independent signaling pathways as depicted in Figure 2. Based on current knowledge, it is more apparent that IGF-IGFBP signaling axes may dictate cell proliferation and affect immune cell function or tissue damage. However, it is uncertain whether IGFBPs expression could impact proinflammatory pathways such cytokine production in the context of autoimmune diseases. Therefore, more delicate mechanistic studies are warranted in order to uncover the molecular and cellular basis and function of IGFBPs in autoimmune diseases.

\section{LOOK INTO THE FUTURE}

In the past decade, there has been a marked change in the way biomarker is discovered since the advent of high throughput techniques such as genomics, proteomics and metabolomics etc. The discovery of biomarkers used to be mechanism-driven, in which researchers choose candidate biomarkers based on their involvement in the pathogenesis of the disease to validate their role as biomarkers for disease diagnosis, disease monitoring, and prognostic evaluation. The investigation of IGFBPs in T1DM was a good example of this mechanism-driven strategy since IGFBP family is involved in insulin regulation, leading to the hypothesis that they might play a pathogenesis role in the development of T1DM. Most of the studies investigating the use of IGFBPs as biomarkers in autoimmune diseases in this review were based on the mechanism-driven strategy. Only two studies used proteomic technique to discover potential biomarkers for T1DM (56) and SLE (89). The untargeted global proteomic biomarker discovery is also called data-driven strategy, in which researchers use high throughput platforms to find potential biomarker from thousands of molecules regardless of their pathogenic role in the development of the disease (105).

Currently studies on IGFBPs role as biomarkers in autoimmune diseases have the following pitfalls. Firstly, most of the studies used conventional strategies instead of "omics" based high-throughput techniques. Future studies should adopt the more efficient and less biased strategy to discover biomarkers in autoimmune diseases. Secondly, almost 
all the studies adopted retrospective case-control study design, in which selection bias cannot be avoided. In the future, prospective studies are highly recommended to validate the existing IGFBPs role as biomarkers in autoimmune diseases. In addition, some IGFBPs such as IGFBP2 were proved to be increased in several different autoimmune diseases including T1DM, MS, RA, SLE, and IBD. It is not clear whether IGFBP2 is a general marker for autoimmunity or it is specific to certain kind of autoimmune diseases. A direct comparison of IGFBP2 levels in patients with these diseases should be helpful in clarifying this issue. Thirdly, the pre-analytical conditions including sample collection and processing for various studies were different, which partially explain the inconsistency of some studies on the validation of the same biomarker in different study population. To overcome

\section{REFERENCES}

1. Kim H-S, Nagalla SR, Oh Y, Wilson E, Roberts CTJ, Rosenfeld RG. Identification of a family of low-affinity insulin-like growth factor binding proteins (IGFBPs): characterization of connective tissue growth factor as a member of the IGFBP superfamily. Proc Natl Acad Sci USA. (1997) 94:12981-6. doi: 10.1073/pnas.94.24.12981

2. Holbourn KP, Acharya KR, Perbal B. The CCN family of proteins: structure-function relationships. Trends Biochem Sci. (2008) 33:461-73. doi: 10.1016/j.tibs.2008.07.006

3. Baxter RC. IGF binding proteins in cancer: mechanistic and clinical insights. Nat Rev Cancer (2014) 14:329-41. doi: 10.1038/nrc3720

4. Bergerot I, Fabien N, Thivolet C. Effects of insulin like growth factor-1 and insulin on effector T cells generating autoimmune diabetes. Diabetes Metab. (1996) 22:235-9.

5. Lovett-Racke AE, Bittner P, Cross AH, Carlino JA, Racke MK. Regulation of experimental autoimmune encephalomyelitis with insulin-like growth factor (IGF-1) and IGF-1/IGF-binding protein-3 complex (IGF-1/IGFBP3). J Clin Invest. (1998) 101:1797-804. doi: 10.1172/JCI1486

6. Bach LA, Headey SJ, Norton RS. IGF-binding proteins-the pieces are falling into place. Trends Endocrinol Metab. (2005) 16:228-34. doi: 10.1016/j.tem.2005.05.005

7. Forbes BE, McCarthy P, Norton RS. Insulin-like growth factor binding proteins: a structural perspective. Front Endocrinol. (2012) 3:38. doi: $10.3389 /$ fendo.2012.00038

8. Bunn RC, Fowlkes JL. Insulin-like growth factor binding protein proteolysis. Trends Endocrinol Metab. (2003) 14:176-81. doi: 10.1016/S1043-2760(03)00049-3

9. Gyrup C, Oxvig C. Quantitative analysis of insulin-like growth factormodulated proteolysis of insulin-like growth factor binding protein- 4 and-5 by pregnancy-associated plasma protein-A. Biochemistry (2007) 46:1972-80. doi: $10.1021 /$ bi062229i

10. Firth SM, Baxter RC. The role of glycosylation in the action of IGFBP-3. Prog Growth Factor Res. (1995) 6:223-9. doi: 10.1016/0955-2235(95)00009-7

11. Coverley JA, Baxter RC. Phosphorylation of insulin-like growth factor binding proteins. Mol Cell Endocrinol. (1997) 128:1-5. doi: 10.1016/S0303-7207(97)04032-X

12. Jones JI, D'Ercole AJ, Camacho-Hubner C, Clemmons DR. Phosphorylation of insulin-like growth factor (IGF)-binding protein 1 in cell culture and in vivo: effects on affinity for IGF-I. Proc Natl Acad Sci USA. (1991) 88:7481585 .

13. Kuang Z, Yao S, McNeil KA, Thompson JA, Bach LA, Forbes BE, et al. Cooperativity of the $\mathrm{N}$ - and $\mathrm{C}$-terminal domains of insulin-like growth factor (IGF) binding protein 2 in IGF binding. Biochemistry (2007) 46:13720-32. doi: 10.1021/bi701251d

14. Adams TE, Epa VC, Garrett TP, Ward CW. Structure and function of the type 1 insulin-like growth factor receptor. Cell Mol Life Sci. (2000) 57:1050-93. doi: $10.1007 /$ PL00000744 this, a standardized protocol for sample handling or biobanking should benefit future studies.

\section{AUTHOR CONTRIBUTIONS}

All authors listed have made a substantial, direct and intellectual contribution to the work, and approved it for publication.

\section{ACKNOWLEDGMENTS}

This work is partly supported by the Lupus Research Alliance (grant number 376484) to TW. The authors acknowledge Mr. Bailey Keyser's assistance in editing the manuscript.

15. Leroith D, Werner H, Beitner-Johnson D, Roberts AT. Molecular and cellular aspects of the insulin-like growth factor I receptor. Endocr Rev. (1995) 16:143-63. doi: 10.1210/edrv-16-2-143

16. Baxter RC. Insulin-like growth factor (IGF) binding proteins: the role of serum IGFBPs in Regulating IGF availability. Acta Paediatr Scand. (1991) 372:107-14. doi: 10.1111/j.1651-2227.1991.tb17983.x

17. Baxter RC. Structure of the Mr 140,000 growth hormone-dependent insulin-like growth factor binding protein complex: determination by reconstitution and affinity-labeling. Proc Natl Acad Sci USA. (1989) 86:6898902. doi: 10.1073/pnas.86.18.6898

18. Jones JI, Clemmons DR. Insulin-like growth factors and their binding proteins: biological actions. Endocr Rev. (1995) 16:3-34.

19. Mohan S, Baylink DJ. IGF-binding proteins are multifunctional and act via IGF-dependent and -independent mechanisms. J Endocrinol. (2002) 175:19-31. doi: 10.1677/joe.0.1750019

20. Jones JI, Clemmons DR. Insulin-like growth factors and their binding proteins: biological actions. Endocr Rev. (1995) 16:3-34.

21. Hwa V, Oh Y, Rosenfeld RG. The insulin-like growth factor-binding protein (IGFBP) superfamily. Endocr Rev. (1999) 20:761-87. doi: 10.1210/er.20.6.761

22. Wang J, Niu W, Witte DP, Chernausek SD, Nikiforov YE, Clemens $\mathrm{TL}$, et al. Overexpression of insulin-like growth factor-binding protein-4 (IGFBP-4) in smooth muscle cells of transgenic mice through a smooth muscle alpha-actin-IGFBP-4 fusion gene induces smooth muscle hypoplasia. Endocrinology (1998) 139:2605-14. doi: 10.1210/endo.139.5.5986

23. Miyakoshi N, Richman C, Qin X, Baylink DJ, Mohan S. Effects of recombinant insulin-like growth factor-binding protein-4 on bone formation parameters in mice. Endocrinology (1999) 140:5719-28. doi: 10.1210/endo.140.12.7175

24. Miyakoshi N, Qin X, Kasukawa Y, Richman C, Srivastava AK, Baylink DJ, et al. Systemic administration of insulin-like growth factor (IGF)binding protein-4 (IGFBP-4) increases bone formation parameters in mice by increasing IGF bioavailability via an IGFBP-4 protease-dependent mechanism. Endocrinology (2001) 142:2641-8. doi: 10.1210/endo.142. 6.8192

25. Firth SM, Baxter RC. Cellular actions of the insulin-like growth factor binding proteins. Endocr Rev. (2002) 23:824-54. doi: 10.1210/er.2001-0033

26. Jones J, Gockerman A, Busby W, Wright G, Clemmons D. Insulin-like growth factor binding protein 1 stimulates cell migration and binds to the alpha 5 beta 1 integrin by means of its Arg-Gly-Asp sequence. Proc Nat Acad Sci USA. (1993) 90:10553-7. doi: 10.1073/pnas.90.22.10553

27. Wang J, Razuvaev A, Folkersen L, Hedin E, Roy J, Brismar K, et al. The expression of IGFs and IGF binding proteins in human carotid atherosclerosis, and the possible role of IGF binding protein-1 in the regulation of smooth muscle cell proliferation. Atherosclerosis (2012) 220:102-9. doi: 10.1016/j.atherosclerosis.2011.10.032

28. Booth BA, Boes M, Dake BL, Bar RS. Isolation and characterization of plasmin-generated bioactive fragments of IGFBP-3. Am J Physiol. (1999) 276:E450-4. doi: 10.1152/ajpendo.1999.276.3.E450 
29. Kansra S, Ewton DZ, Wang J, Friedman E. IGFBP-3 mediates TGF beta 1 proliferative response in colon cancer cells. Int J Cancer (2000) 87:373-8. doi: 10.1002/1097-0215(20000801)87:3\&lt;373::AID-IJC10\&gt;3.0.CO;2-X

30. Cohen P, Rajah R, Rosenbloom J, Herrick DJ. IGFBP-3 mediates TGF-beta 1induced cell growth in human airway smooth muscle cells. Am J Physiol Lung Cell Mol Physiol. (2000) 278:L545-51. doi: 10.1152/ajplung.2000.278.3.L545

31. Rozen F, Zhang J, Pollak M. Antiproliferative action of tumor necrosis factoralpha on MCF-7 breastcancer cells is associated with increased insulin-like growth factor binding protein-3 accumulation. Int J Oncol. (1998) 13:865-9. doi: 10.3892/ijo.13.4.865

32. Spagnoli A, Hwa V, Horton WA, Lunstrum GP, Roberts CT, Chiarelli $\mathrm{F}$, et al. Antiproliferative effects of insulin-like growth factor-binding protein-3 in mesenchymal chondrogenic cell line RCJ3.1C5.18. Relationship to differentiation stage. J Biol Chem. (2001) 276:5533-40. doi: 10.1074/jbc.M005088200

33. Valentinis B, Bhala A, DeAngelis T, Baserga R, Cohen P. The human insulinlike growth factor (IGF) binding protein-3 inhibits the growth of fibroblasts with a targeted disruption of the IGF-I receptor gene. Mol Endocrinol. (1995) 9:361-7.

34. Cohen P, Lamson G, Okajima T, Rosenfeld RG. Transfection of the human IGFBP-3 gene into Balb/c fibroblasts: a model for the cellular functions of IGFBPs. Growth Regul. (1993) 3:23-6.

35. Zhang Q, Steinle JJ. IGFBP-3 inhibits TNF- $\alpha$ production and TNFR-2 signaling to protect against retinal endothelial cell apoptosis. Microvasc Res. (2014) 95:76-81. doi: 10.1016/j.mvr.2014.07.009

36. Lee Y-C, Jogie-Brahim S, Lee D-Y, Han J, Harada A, Murphy LJ, et al. Insulin-like growth factor-binding protein-3 (IGFBP-3) blocks the effects of asthma by negatively regulating NF- $\mathrm{B}$ signaling through IGFBP3R-mediated activation of caspases. J Biol Chem. (2011) 286:17898-909. doi: 10.1074/jbc.M111.231035

37. Andress DL, Birnbaum RS. Human osteoblast-derived insulin-like growth factor (IGF) binding protein-5 stimulates osteoblast mitogenesis and potentiates IGF action. J Biol Chem. (1992) 267:22467-72.

38. Richman C, Baylink DJ, Lang K, Dony C, Mohan S. Recombinant human insulin-like growth factor-binding protein-5 stimulates bone formation parameters in vitro and in vivo. Endocrinology (1999) 140:4699-705. doi: 10.1210/endo.140.10.7081

39. Miyakoshi N, Richman C, Kasukawa Y, Linkhart TA, Baylink DJ, Mohan $\mathrm{S}$. Evidence that IGF-binding protein-5 functions as a growth factor. J Clin Invest. (2001) 107:73-81. doi: 10.1172/JCI10459

40. Tripathi G, Salih DAM, Drozd AC, Cosgrove RA, Cobb LJ, Pell JM. IGFindependent effects of insulin-like growth factor binding protein-5 (Igfbp5) in vivo. FASEB J. (2009) 23:2616-26. doi: 10.1096/fj.08-114124

41. Cobb LJ, Salih DAM, Gonzalez I, Tripathi G, Carter EJ, Lovett F, et al. Partitioning of IGFBP-5 actions in myogenesis: IGF-independent anti-apoptotic function. J Cell Sci. (2004) 117:1737-46. doi: 10.1242/jcs. 01028

42. Gershtein ES, Isaeva ER, Kushlinsky DN, Korotkova EA, Ermilova VD, Laktionov KP, et al. Insulin-like growth factors (IGF) and IGF-binding proteins (IGFBP) in the serum of patients with ovarian tumors. Bull Exp Biol Med. (2016) 160:814-6. doi: 10.1007/s10517-016-3317-2

43. Yoneyama T, Ohtsuki S, Honda K, Kobayashi M, Iwasaki M, Uchida Y, et al. Identification of IGFBP2 and IGFBP3 as compensatory biomarkers for CA19-9 in early-stage pancreatic cancer using a combination of antibodybased and LC-MS/MS-based proteomics. PLoS ONE (2016) 11:e0161009. doi: 10.1371/journal.pone.0161009

44. Bao L, Liu H, You B, Gu M, Shi S, Shan Y, et al. Overexpression of IGFBP3 is associated with poor prognosis and tumor metastasis in nasopharyngeal carcinoma. Tumour Biol. (2016) 37:15043-52. doi: $10.1007 /$ s13277-016-5400-8

45. Gianuzzi X, Palma-Ardiles G, Hernandez-Fernandez W, Pasupuleti V, Hernandez AV, Perez-Lopez FR. Insulin growth factor (IGF) 1, IGF-binding proteins and ovarian cancer risk: a systematic review and meta-analysis. Maturitas (2016) 94:22-9. doi: 10.1016/j.maturitas.2016.08.012

46. Kalfert D, Ludvikova M, Topolcan O, Celakovsky P, Kucera R, Windrichova J, et al. Serum levels of IGF-1 and IGFBP-3 in relation to clinical and pathobiological aspects of head and neck squamous cell carcinomas. Anticancer Res. (2017) 37:3281-6. doi: 10.21873/anticanres.11693
47. Radetti G, Paganini C, Antoniazzi F, Pasquino B, Valentini R, Gentili L, et al. Growth hormone-binding proteins, IGF-I and IGF-binding proteins in children and adolescents with type 1 diabetes mellitus. Horm Res. (1997) 47:110-5. doi: 10.1159/000185444

48. Wacharasindhu S, Srivuthana S, Aroonparkmongkol S. Insulin-like growth factors and their binding proteins in children with IDDM. J Med Assoc Thail. (2002) 85:41-52.

49. Riihimaa PH, Knip M, Ruokonen A, Tapanainen P. Lack of physiological suppression of circulating IGFBP-1 in puberty in patients with insulindependent diabetes mellitus. Eur J Endocrinol. (2002) 147:235-41. doi: 10.1530 /eje.0.1470235

50. Levitt Katz LE, Jawad AF, Ganesh J, Abraham M, Murphy K, Lipman TH. Fasting c-peptide and insulin-like growth factor-binding protein-1 levels help to distinguish childhood type 1 and type 2 diabetes at diagnosis. Pediatr. Diabetes (2007) 8:53-9. doi: 10.1111/j.1399-5448.2007.00236.x

51. Frystyk J, Bek T, Flyvbjerg A, Skjærbæk C, Ørskov H. The relationship between the circulating IGF system and the presence of retinopathy in Type 1 diabetic patients. Diabet Med. (2003) 20:269-76. doi: 10.1046/j.1464-5491.2003.00921.x

52. Sorensen JS, Birkebaek NH, Bjerre M, Pociot F, Kristensen K, Hoejberg AS, et al. Residual $\beta$-cell function and the insulin-like growth factor system in Danish children and adolescents with type 1 diabetes. J Clin Endocrinol Metab. (2015) 100:1053-61. doi: 10.1210/jc.2014-3521

53. Wedrychowicz A, Dziatkowiak H, Nazim J, Sztefko K. Insulin-like growth factor- 1 and its binding proteins, IGFBP-1 and IGFBP-3, in adolescents with type-1 diabetes mellitus and microalbuminuria. Horm Res. (2005) 63:245-51. doi: 10.1159/000085941

54. Feldmann B, Jehle PM, Mohan S, Lang GE, Lang GK, Brueckel J, et al. Diabetic retinopathy is associated with decreased serum levels of free IGFI and changes of IGF-binding proteins. Growth Horm IGF Res. (2000) 10:53-60. doi: 10.1054/ghir.2000.0140

55. Knip M, Tapanainen P, Pekonen F, Blum WF. Insulin-like growth factor binding proteins in prepubertal children with insulin-dependent diabetes mellitus. Eur J Endocrinol. (1995) 133:440-4. doi: 10.1530/eje.0.1330440

56. Zhi W, Sharma A, Purohit S, Miller E, Bode B, Anderson SW, et al. Discovery and validation of serum protein changes in type 1 diabetes patients using high throughput two dimensional liquid chromatographymass spectrometry and immunoassays. Mol Cell Proteomics (2011) 10:M111.012203. doi: 10.1074/mcp.M111.012203

57. Loukovaara S, Immonen IJR, Koistinen R, Rutanen EM, Hiilesmaa V, Loukovaara $\mathrm{M}$, et al. The insulin-like growth factor system and type 1 diabetic retinopathy during pregnancy. J Diabetes Complic. (2005) 19:297304. doi: 10.1016/j.jdiacomp.2005.03.004

58. Higgins MF, Russell NE, Crossey PA, Nyhan KC, Brazil DP, McAuliffe FM. Maternal and fetal placental growth hormone and IGF axis in type 1 diabetic pregnancy. PLoS ONE (2012) 7:e29164. doi: 10.1371/journal.pone.00 29164

59. Kim MS, Lee DY. Serum insulin-like growth factor-binding protein-3 level correlated with glycemic control and lipid profiles in children and adolescents with type 1 diabetes. J Pediatr Endocrinol Metab. (2014) 27:85761. doi: 10.1515/jpem-2013-0358

60. Capoluongo E, Pitocco D, Lulli P, Minucci A, Santonocito C, Manto A, et al. Inverse correlation between serum free IGF-I and IGFBP-3 levels and blood pressure in patients affected with type 1 diabetes. Cytokine (2006) 34:303-11. doi: 10.1016/j.cyto.2006.06.007

61. Capoluongo E, Pitocco D, Santonocito C, Concolino P, Santini SA, Manto A, et al. Association between serum free IGF-I and IGFBP-3 levels in type-I diabetes patients affected with associated autoimmune diseases or diabetic complications. Eur Cytokine Netw. (2006) 17:167-74. doi: 10.1684/ecn.2006.0036

62. Wu Y-C, Buckner BR, Zhu M, Cavanagh HD, Robertson DM. Elevated IGFBP3 levels in diabetic tears: a negative regulator of IGF1 signaling in the corneal epithelium. Ocul Surf. (2012) 10:100-7. doi: 10.1016/j.jtos.2012.01.004

63. Hjortebjerg R, Tarnow L, Jorsal A, Parving HH, Rossing P, Bjerre M, et al. IGFBP-4 Fragments as markers of cardiovascular mortality in Type 1 diabetes patients with and without nephropathy. J Clin Endocrinol Metab. (2015) 100:3032-40. doi: 10.1210/jc.2015-2196 
64. Wilczak N, Schaaf M, Bredewold R, Streefland C, Teelken A, De Keyser J. Insulin-like growth factor system in serum and cerebrospinal fluid in patients with multiple sclerosis. Neurosci Lett. (1998) 257:168-70.

65. Al-Temaimi R, AbuBaker J, Al-khairi I, Alroughani R. Remyelination modulators in multiple sclerosis patients. Exp Mol Pathol. (2017) 103:237-41. doi: 10.1016/j.yexmp.2017.11.004

66. Wilczak N, Chesik D, Hoekstra D, De Keyser J. IGF binding protein alterations on periplaque oligodendrocytes in multiple sclerosis: implications for remyelination. Neurochem Int. (2008) 52:1431-5. doi: 10.1016/j.neuint.2008.03.004

67. Lanzillo R, Di Somma C, Quarantelli M, Ventrella G, Gasperi $\mathrm{M}$, Prinster A, et al. Insulin-like growth factor (IGF)-I and IGFbinding protein-3 serum levels in relapsing-remitting and secondary progressive multiple sclerosis patients. Eur J Neurol. (2011) 18:1402-6. doi: 10.1111/j.1468-1331.2011.03433.x

68. Akcali A, Bal B, Erbagci B. Circulating IGF-1, IGFB-3, GH and TSH levels in multiple sclerosis and their relationship with treatment. Neurol Res. (2017) 39:606-11. doi: 10.1080/01616412.2017.1321711

69. Hosback S, Hardiman O, Nolan CM, Doyle MAC, Gorman G, Lynch C, et al. Circulating insulin-like growth factors and related binding proteins are selectively altered in amyotrophic lateral sclerosis and multiple sclerosis. Growth Horm IGF Res. (2007) 17:472-9. doi: 10.1016/j.ghir.2007.06.002

70. Wilczak N, Ramsaransing G, Mostert J, Chesik D, De Keyser J. Serum levels of insulin-like growth factor-1 and insulin-like growth factor binding protein-3 in relapsing and primary progressive multiple sclerosis. Mult Scler. (2005) 11:13-5. doi: 10.1191/1352458505ms1123oa

71. Matsumoto T, Yamashita S, Rosenfeld RG. Increased levels of IGF-I and IGFBP-3 in synovial fluids of patients with rheumatoid arthritis. Endocr J. (1998) 45(Suppl):S141-4. doi: 10.1507/endocrj.45.Suppl_S141

72. Tavera C, Abribat T, Reboul P, Dore S, Brazeau P, Pelletier JP, et al. IGF and IGF-binding protein system in the synovial fluid of osteoarthritic and rheumatoid arthritic patients. Osteoarthr Cartil. (1996) 4:263-74. doi: 10.1016/S1063-4584(05)80104-9

73. Fernihough JK, Billingham MEJ, Cwyfan-Hughes S, Holly JMP. Local disruption of the insulin-like growth factor system in the arthritic joint. Arthritis Rheum. (1996) 39:1556-65. doi: 10.1002/art.17803 90916

74. Matsumoto T, Gargosky SE, Iwasaki K, Rosenfeld RG. Identification and characterization of insulin-like growth factors (IGFs), IGF-binding proteins (IGFBPs), and IGFBP proteases in human synovial fluid. J Clin Endocrinol Metab. (1996) 81:150-5.

75. Lemmey A, Maddison P, Breslin A, Cassar P, Hasso N, McCann R, et al. Association between insulin-like growth factor status and physical activity levels in rheumatoid arthritis. J Rheumatol. (2001) 28:29-34.

76. Lee SD, Chen LM, Kuo WW, Shu WT, Kuo WH, Huang EJ, et al. Serum insulin-like growth factor-axis and matrix metalloproteinases in patients with rheumatic arthritis or rheumatic heart disease. Clin Chim Acta (2006) 367:62-8. doi: 10.1016/j.cca.2005.11.015

77. Melikoglu MA, Karatay S, Senel K, Akcay F. Association between dynamic exercise therapy and IGF-1 and IGFBP-3 concentrations in the patients with rheumatoid arthritis. Rheumatol Int. (2006) 26:309-13. doi: 10.1007/s00296-005-0605-y

78. Karatay S, Yildirim K, Melikoglu MA, Akcay F, Senel K. Effects of dynamic exercise on circulating IGF-1 and IGFBP-3 levels in patients with rheumatoid arthritis or ankylosing spondylitis. Clin Rheumatol. (2007) 26:1635-9. doi: 10.1007/s10067-007-0559-4

79. Toussirot E, Nguyen NU, Dumoulin G, Aubin F, Cédoz J-P, Wendling D. Relationship between growth hormone-IGF-I-IGFBP-3 axis and serum leptin levels with bone mass and body composition in patients with rheumatoid arthritis. Rheumatology (2005) 44:120-5. doi: 10.1093/rheumatology/keh421

80. Matsumoto T, Tsurumoto T. Inappropriate serum levels of IGF-I and IGFBP3 in patients with rheumatoid arthritis. Rheumatology (2002) 41:352-3. doi: 10.1093/rheumatology/41.3.352

81. Neidel J. Changes in systemic levels of insulin-like growth factors and their binding proteins in patients with rheumatoid arthritis. Clin Exp Rheumatol. (2001) 19:81-4.
82. Suzuki S, Morimoto S, Fujishiro M, Kawasaki M, Hayakawa K, Miyashita $\mathrm{T}$, et al. Inhibition of the insulin-like growth factor system is a potential therapy for rheumatoid arthritis. Autoimmunity (2015) 48:251-8. doi: 10.3109/08916934.2014.976631

83. Engvall IL, Elkan AC, Tengstrand B, Cederholm T, Brismar K, Hafström I. Cachexia in rheumatoid arthritis is associated with inflammatory activity, physical disability, and low bioavailable insulin-like growth factor. Scand J Rheumatol. (2008) 37:321-8. doi: 10.1080/030097408020 55984

84. Wong SC, MacRae VE, Gracie JA, McInnes IB, Galea P, Gardner-Medwin J, et al. Inflammatory cytokines in juvenile idiopathic arthritis: effects on physical growth and the insulin-like-growth factor axis. Growth Horm IGF Res. (2008) 18:369-78. doi: 10.1016/j.ghir.2008.01.006

85. Guszczyn T, Rzeczycka J, Popko J. IGF-I and IGF-binding proteins in articular exudates of children with post-traumatic knee damage and juvenile idiopathic arthritis. Pathobiology (2009) 76:260-6. doi: 10.1159/000228902

86. De Benedetti F, Meazza C, Oliveri M, Pignatti P, Vivarelli M, Alonzi T, et al. Effect of IL-6 on IGF binding protein-3: a study in IL-6 transgenic mice and in patients with systemic juvenile idiopathic arthritis. Endocrinology (2001) 142:4818-26. doi: 10.1210/endo.142.11.8511

87. Wu T, Xie C, Han J, Ye Y, Singh S, Zhou J, et al. Insulin-like growth factor binding protein-4 as a marker of chronic lupus nephritis. PLOS ONE (2016) 11:e0151491. doi: 10.1371/journal.pone.0151491

88. Ding $\mathrm{H}$, Kharboutli $\mathrm{M}$, Saxena $\mathrm{R}, \mathrm{Wu} \mathrm{T}$. Insulin-like growth factor binding protein-2 as a novel biomarker for disease activity and renal pathology changes in Lupus nephritis. Clin Exp Immunol. (2016) 184:11-8. doi: $10.1111 /$ cei. 12743

89. Wu T, Ding H, Han J, Arriens C, Wei C, Han W, et al. Antibodyarray-based proteomic screening of serum markers in systemic Lupus erythematosus: a discovery study. J Proteome Res. (2016) 15:2102-14. doi: 10.1021/acs.jproteome.5b00905

90. Mok CC, Ding HH, Kharboutli M, Mohan C. Axl, ferritin, insulin-like growth factor binding protein 2, and tumor necrosis factor receptor Type II as biomarkers in systemic Lupus erythematosus. Arthritis Care Res. (2016) 68:1303-9. doi: 10.1002/acr.22835

91. Hamaguchi Y, Fujimoto M, Matsushita T, Hasegawa M, Takehara K, Sato S. Elevated serum insulin-like growth factor (IGF-1) and IGF binding protein3 levels in patients with systemic sclerosis: possible role in development of fibrosis. J Rheumatol. (2008) 35:2363-71. doi: 10.3899/jrheum. 080340

92. Yasuoka H, Jukic DM, Zhou Z, Choi AMK, Feghali-Bostwick CA. Insulinlike growth factor binding protein 5 induces skin fibrosis: a novel murine model for dermal fibrosis. Arthritis Rheum. (2006) 54:3001-10. doi: 10.1002/art.22084

93. Yasuoka H, Zhou Z, Pilewski JM, Oury TD, Choi AMK, Feghali-Bostwick CA. Insulin-like growth factor-binding protein-5 induces pulmonary fibrosis and triggers mononuclear cellular infiltration. Am J Pathol. (2006) 169:163342. doi: 10.2353/ajpath.2006.060501

94. Hathout Y, Conklin LS, Seol H, Gordish-Dressman H, Brown KJ, Morgenroth LP, et al. Serum pharmacodynamic biomarkers for chronic corticosteroid treatment of children. Sci Rep. (2016) 6:31727. doi: 10.1038/srep31727

95. Guiot J, Bondue B, Henket M, Corhay JL, Louis R. Raised serum levels of IGFBP-1 and IGFBP-2 in idiopathic pulmonary fibrosis. BMC Pulm Med. (2016) 16:86. doi: 10.1186/s12890-016-0249-6

96. Smith TJ. Insulin-like growth factor-I regulation of immune function: a potential therapeutic target in autoimmune diseases? Pharmacol Rev. (2010) 62:199-236. doi: 10.1124/pr.109.002469

97. Stanilova SA, Ivanova MG, Karakolev IA, Stoilov RM, Rashkov RK, Manolova IM. Association of +3179G/A insulin-like growth factor1 receptor polymorphism and insulin-like growth factor-1 serum level with systemic lupus erythematosus. Lupus (2013) 22:1388-93. doi: $10.1177 / 0961203313502860$

98. Hettmer S, Dannecker L, Foell J, Elmlinger MW, Dannecker GE. Effects of insulin-like growth factors and insulin-like growth factor binding protein2 on the in vitro proliferation of peripheral blood mononuclear cells. Hum Immunol. (2005) 66:95-103. doi: 10.1016/j.humimm.2004.10.014 
99. Agnese DM, Calvano JE, Hahm SJ, Calvano SE, Lowry SF. Insulinlike growth factor binding protein-3 is upregulated in LPS-treated THP-1 cells. Surg Infect. (2002) 3:116-9. doi: 10.1089/1096296027601 05781

100. Zhang Q, Jiang Y, Toutounchian JJ, Soderland C, Yates CR, Steinle JJ. Insulinlike growth factor binding protein-3 inhibits monocyte adhesion to retinal endothelial cells in high glucose conditions. Mol Vis. (2013) 19:796-803.

101. Yasuoka H, Yamaguchi Y, Feghali-Bostwick CA. The pro-fibrotic factor IGFBP-5 induces lung fibroblast and mononuclear cell migration. Am J Respir Cell Mol Biol. (2009) 41:179-88. doi: 10.1165/rcmb.200802110C

102. Taguchi T, Takenouchi H, Matsui J, Tang WR, Itagaki M, Shiozawa Y, et al. Involvement of insulin-like growth factor-I and insulin-like growth factor binding proteins in pro-B-cell development. Exp Hematol. (2006) 34:508-18. doi: 10.1016/j.exphem.2006.01.009

103. Chen J, Li J, Lim FC, Wu Q, Douek DC, Scott DK, et al. Maintenance of naïve CD8 T cells in nonagenarians by leptin, IGFBP3 and T3. Mech Ageing Dev. (2010) 131:29-37. doi: 10.1016/j.mad.2009.11.003
104. Ventura Ferreira MS, Labude N, Walenda G, Adamzyk C, Wagner W, Piroth $\mathrm{D}$, et al. Ex vivo expansion of cord blood-CD34+ cells a using IGFBP2 and Angptl-5 impairs short-term lymphoid repopulation in vivo. J Tissue Eng Regen Med. (2013) 7:944-54. doi: 10.1002/term.1486

105. Yoo BC, Kim K-H, Woo SM, Myung JK. Clinical multi-omics strategies for the effective cancer management. J Proteomics (2017). doi: 10.1016/j.jprot.2017.08.010. [Epub ahead of print].

Conflict of Interest Statement: The authors declare that the research was conducted in the absence of any commercial or financial relationships that could be construed as a potential conflict of interest.

Copyright (C) 2018 Ding and Wu. This is an open-access article distributed under the terms of the Creative Commons Attribution License (CC BY). The use, distribution or reproduction in other forums is permitted, provided the original author(s) and the copyright owner(s) are credited and that the original publication in this journal is cited, in accordance with accepted academic practice. No use, distribution or reproduction is permitted which does not comply with these terms. 